\title{
Invariant natural killer T cells regulate anti-tumor immunity by controlling the population of dendritic cells in tumor and draining lymph nodes
}

Karsten A Pilones ${ }^{1}$, Joseph Aryankalayil ${ }^{1}$, James S Babb² and Sandra Demaria ${ }^{1,3,4^{*}}$

\begin{abstract}
Background: Invariant natural killer T (iNKT) cells are CD1d-restricted T cells, which respond rapidly to antigen recognition and promote development of anti-tumor immunity in many tumor models. Surprisingly, we previously found that mice deficient in iNKT cells developed spontaneous $C D 8^{+} T$ cells responses partially effective at inhibiting metastases in mice bearing the 4T1 mammary carcinoma, and showed a markedly improved response to treatment with local radiotherapy and anti-CTLA-4 antibody compared to wild type (WT) mice.

Methods: To understand the mechanisms of the immunosuppressive function of iNKT cells, dendritic cells (DCs) were analyzed by immunohistochemistry and flow cytometry in WT and iNKT-deficient (iNKT ${ }^{-}$) mice. The effects of antibody-mediated blockade of CD1d on DC number and phenotype, priming of anti-tumor T cells, and tumor response to treatment with local radiotherapy and anti-CTLA-4 antibody were evaluated. To determine if the improved response to treatment in the absence of iNKT cells was independent from the immunotherapy employed, 4T1-tumor bearing $\mathrm{WT}$ and $\mathrm{iNKT}^{-1-}$ mice were treated with local radiotherapy in combination with antibody-mediated CD137 co-stimulation.
\end{abstract}

Results: DCs in 4T1 tumors and tumor-draining lymph nodes but not distant lymph nodes were significantly reduced in WT mice compared to iNKT ${ }^{--}$mice $(p<0.05)$, suggesting the selective elimination of DCs cross-presenting tumor-associated antigens by iNKT cells. Consistently, priming of T cells to a tumor-specific CD8 T cell epitope in mice treated with radiotherapy and anti-CTLA-4 or anti-CD137 was markedly enhanced in iNKT ${ }^{-/-}$compared to WT mice. CD1d blockade restored the number of DC in WT mice, improved T cell priming in draining lymph nodes and significantly enhanced response to treatment.

Conclusions: Here we describe a novel mechanism of tumor immune escape mediated by iNKT cells that limit priming of anti-tumor T cells by controlling DC in tumors and draining lymph nodes. These results have important implications for the design of immunotherapies targeting iNKT cells.

Keywords: Breast cancer, CD1d, CD137, CTLA-4, CD8 ${ }^{+}$T-cells, Dendritic cells, Immunoregulation, Invariant NKT cells, Radiotherapy

\footnotetext{
* Correspondence: Sandra.Demaria@nyumc.org

'Department of Pathology, New York University School of Medicine, New

York, NY 10016, USA

${ }^{3}$ Department of Radiation Oncology, New York University School of

Medicine, New York, NY 10016, USA

Full list of author information is available at the end of the article
} 


\section{Background}

Natural killer T (NKT) cells comprise a subset of lymphocytes originating from a distinct developmental lineage [1] which bridge innate and adaptive immunity and modulate immune responses in autoimmunity, malignancies and infections [2]. Although initially identified by co-expression of conventional $\alpha \beta$ T-cell receptors (TCR) and markers typically associated with natural killer (NK) cells [3], NKT are currently distinguished on the basis of CD1d restriction as well as specific usage of TCR $\alpha$ chains [4]. In both mice and humans, most NKT cells express TCRs formed by the rearrangement of a canonical $\alpha$ chain $(\mathrm{V} \alpha 14$ in mice, $V \alpha 24$ in humans) and a limited set of $V \beta$ chains (V $\beta .2, V \beta 7, V \beta 2$ in mice, $V \beta 11$ in humans) and are commonly referred to as type I or invariant natural killer $\mathrm{T}$ (iNKT) cells [5,6]. A smaller NKT cell subset utilizes a more diverse set of TCR $\alpha \beta$ chains and is referred to as type II or non-invariant NKT cells [7].

Identification of $\alpha$-galactosylceramide $(\alpha$-GalCer) as a strong agonist selective for iNKT cells [8] facilitated their characterization using $\alpha$-GalCer-loaded CD1d tetramers [9]. In several tumor models, iNKT cells were found to perform important immunosurveillance functions and become key effectors of tumor rejection when activated by $\alpha$-GalCer [10-13]. Expression of high levels of Fas Ligand, perforin, and granzyme B by iNKT cells underlies their cytolytic activity against $\mathrm{CD} \mathrm{d}^{+}$tumor cells [14] and myeloid cells with immunosuppressive function present in the tumor microenvironment [15]. In addition, iNKT cells exert anti-tumor functions by rapid and robust secretion of cytokines that improve DC ability to cross-prime antitumor $\mathrm{T}$ cells $[10,12,16,17]$ and enhance recruitment of other effectors such as NK cells, CD4 ${ }^{+} \mathrm{T}$ helper-1 (Th1) and $\mathrm{CD}^{+}$cytotoxic $\mathrm{T}(\mathrm{CTL})$ cells $[13,18]$.

Experimental data in different systems indicate a functional plasticity of iNKT cells. iNKT cells can promote the polarization of adaptive immune responses towards both Th1 and Th2 and can secrete immunosuppressive cytokines [19]. The regulatory function of iNKT cells has been demonstrated in multiple models of autoimmune diseases in which iNKT cells played essential roles in maintenance of tolerance [20-22]. The mechanisms that determine whether iNKT cells act to promote immune activation or tolerance remain incompletely understood, but the inflammatory context in which interactions of iNKT cells with $\mathrm{CD} 1 \mathrm{~d}^{+}$myeloid cells take place is thought to be a key factor [23,24].

The 4T1 mouse mammary carcinoma is a model for triple negative breast cancer and shows an aggressive behavior with rapid spread of metastatic cells to the lungs after subcutaneous injection. We previously found that 4T1 tumor-bearing iNKT-deficient $\left(\mathrm{iNKT}^{-/-}\right.$) mice developed a spontaneous $\mathrm{CD}^{+} \mathrm{T}$ cell response that was partially effective at controlling metastases in the lungs [25].
Response to treatment with local radiotherapy and antiCTLA-4 monoclonal antibody (mAb) was also markedly improved in iNKT ${ }^{-/-}$compared to wild type (WT) mice with half of the mice rejecting completely the primary irradiated tumor and lung metastases and showing longterm survival compared to none of the WT mice [25]. These data implicated iNKT cells as major regulators of the spontaneous as well as immunotherapy-elicited antitumor immune response to $4 \mathrm{~T} 1$ tumor.

$\mathrm{CD}^{+}{ }^{+}$regulatory $\mathrm{T}$ cells (Treg) have been shown to limit the development of anti-tumor T cells by killing DCs in tumor-draining lymph nodes (dLN) [26]. DCs are a major subset of $\mathrm{CD} 1 \mathrm{~d}^{+}$antigen-presenting cells (APC) that interact with iNKT cells. Therefore, we hypothesized that iNKT cells may be limiting the anti-tumor immune response in $4 \mathrm{~T} 1$ tumor-bearing mice by controlling the loco-regional population of DCs in the tumor and dLNs. For the first time, we present evidence that WT mice have reduced numbers of DCs in tumor and dLN compared to $\mathrm{iNKT}^{-1-}$ mice, and reduced priming of tumor-specific $\mathrm{CD}^{+} \mathrm{T}$ cells, as measured by gamma interferon (IFN $\gamma$ ) production in response to a $\mathrm{H} 2-\mathrm{L}^{\mathrm{d}}$-restricted peptide derived from a tumor antigen. DC numbers and tumorspecific $\mathrm{CD}^{+} \mathrm{T}$ cell responses were at least partially restored by blocking $\mathrm{CD} 1 \mathrm{~d}$, resulting in improved response to immunotherapy. Overall, data demonstrate a novel mechanism of immune escape mediated by iNKT cells.

\section{Results}

Numbers of DCs infiltrating $4 \mathrm{~T} 1$ tumors and dLN are lower in WT compared to iNKT ${ }^{-/-}$mice

We hypothesized that the interaction of iNKT cells with CD1d ${ }^{+}$APC could modulate the ability of WT mice to develop anti-tumor immune responses upon treatment. To test this hypothesis we compared DCs in healthy and tumor-bearing WT and $\mathrm{iNKT}^{-1-}$ mice. iNKT ${ }^{-1-}$ mice were generated by targeted deletion of the Ja18 segment of the T-cell receptor (TCR) and show selective loss of the Vo14Jo18 TCR expressed by iNKT cells while other lymphoid and myeloid populations are not affected [27]. Consistently, there were no differences in the number of DCs present in LNs or their expression of maturation markers CD80 and CD86, including CD1d, between WT and $\mathrm{iNKT}^{-/-}$healthy mice (Figure $1 \mathrm{~A}$ and $\mathrm{B}$ ). In contrast, after $4 \mathrm{~T} 1$ tumor implantation there was a difference in the numbers of DCs in the tumor-draining but not distant LNs (Figure 1C and D), with significantly lower numbers of DCs present in WT compared to $\mathrm{iNKT}^{-1-}$ mice. Significantly lower numbers of DCs were also found in the tumors growing in WT compared to $\mathrm{iNKT}^{-1-}$ mice (Figure 1E and F). Interestingly, while non-draining LNs of iNKT ${ }^{-/-}$mice showed a DC density comparable to LNs of healthy mice, DC density was markedly increased in tumor-draining LNs, suggesting 

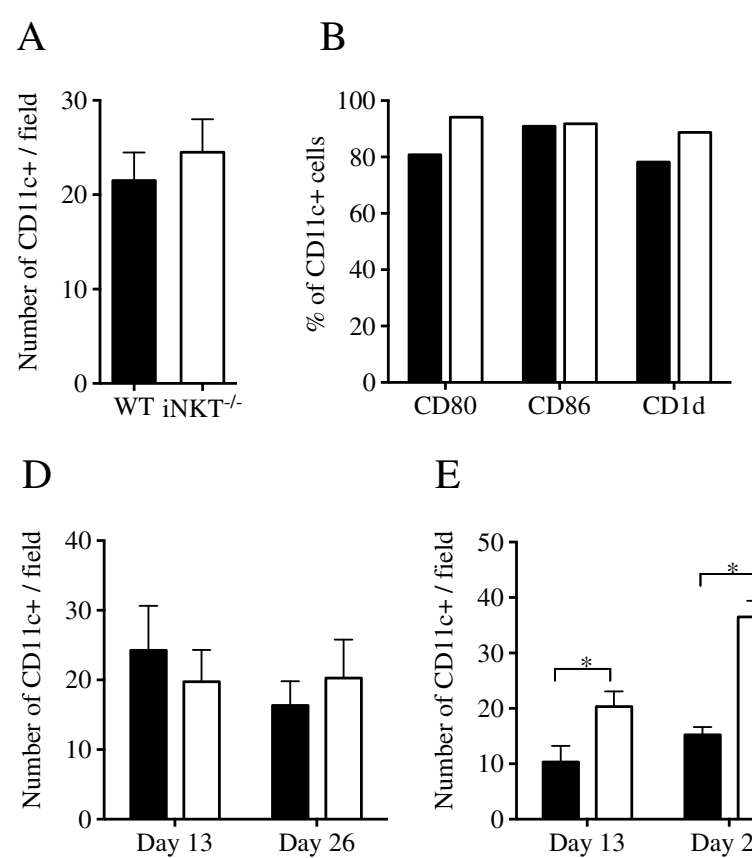

$\mathrm{E}$
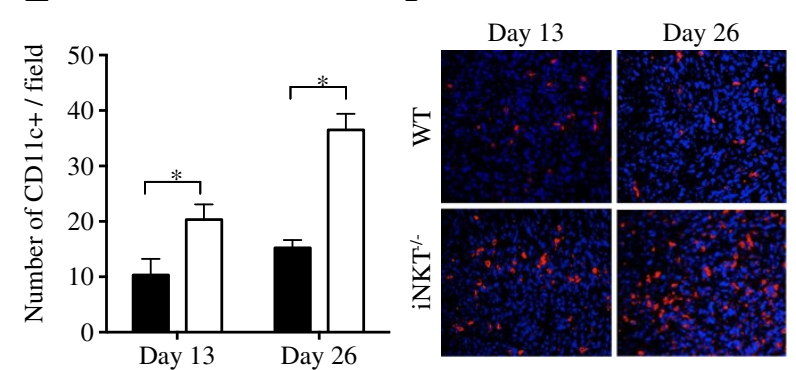

Figure 1 iNKT cells regulate the number of DCs in 4 T1 tumors and draining lymph nodes. (A, B) Lymph nodes collected from healthy WT (black bars) and iNKT ${ }^{--}$(white bars) mice ( $\mathrm{N}=3 /$ strain). (A) Full-face lymph node sections were stained with anti-CD11c mAb and positive cells counted. (B) Dissociated lymph node cells were gated on CD11C + cells and expression of CD1d and co-stimulatory molecules CD80 and CD86 determined by flow cytometry. (C-F) WT (black bars) and iNKT ${ }^{-1}$ (white bars) mice were inoculated s.c. with 4T1 cells. On indicated days, tumor-draining lymph nodes (C), non-draining lymph nodes (D), and tumors (E, F) were excised, tissue sections stained with anti-CD11C $\mathrm{mAb}$ and positive cells counted. Numbers are the mean \pm SD of 3 mice of each strain analyzed at each time point. (F) Representative fields (400x magnification). Results are representative of two experiments. ${ }^{*} p<0.05$.

that even in the absence of treatment the presence of the growing tumor leads to some activation of the regional immune system. This finding is consistent with the presence of a spontaneous anti-tumor $\mathrm{CD}^{+} \mathrm{T}$ cell response in $\mathrm{iNKT}^{-/-}$mice that was partially effective at controlling metastases in the lungs as we have previously reported [25].

Overall, data suggest that in WT mice iNKT cells may control the population of DCs in the tumor and dLN thus precluding the priming of anti-tumor T cells.

\section{CD1d blockade restores DC numbers and improves tumor-specific T cell cross-priming in WT 4T1 tumor-bearing mice}

Elimination of DCs in dLN has been shown to be one mechanism whereby Treg suppress the anti-tumor immune response [26]. To determine if iNKT cells could be responsible for the reduction in the number of DCs in tumors and dLN of WT mice we tested whether inhibiting their interaction with DCs with a mAb that blocks CD1d [28] would lead to increased DC numbers. First, we confirmed that the anti-CD1d mAb used (20H2) was able to inhibit the interaction of the DN32.D3 iNKT-like hybridoma cells with $\alpha$-GalCer-loaded DCs in vitro in a dose-dependent manner (Additional file 1: Figure S1). In addition, we verified that administration of $20 \mathrm{H} 2 \mathrm{mAb}$ to mice did not cause the depletion of $\mathrm{CD} 1 \mathrm{~d}^{+}$cells (Additional file 2: Figure S2) nor induce their stimulation by reverse signaling (Additional file 3: Figure S3). Next, anti-CD1d mAb was given to 4T1 tumor-bearing WT mice starting on day 3 post-tumor inoculation and tumors and dLN analyzed at day 13 , a time when tumors are irradiated in treated mice and the availability of DCs that can cross-present the tumor antigens released by radiation is critical $[29,30]$. CD1d blockade led to a significant increase in the total number of DCs present in tumors and dLNs (Figure 2A). Both immunostimulatory $\mathrm{CD} 8 \alpha+$ and CD $8 \alpha-\mathrm{DC}$ subsets were increased (Figure $2 \mathrm{~B}$ ), whereas expression of activation markers CD40, CD70, CD86, and of MHC Class I molecules in either subsets of tumor infiltrating DCs were not altered by CD1d blockade (Figure 2C-F). Therefore, data indicate that iNKT cells regulate DC numbers in $4 \mathrm{~T} 1$ tumor-bearing WT mice via CD1d-mediated interactions.

To determine if blockade of CD1d resulted in improved priming of anti-tumor $\mathrm{CD}^{+} \mathrm{T}$ cells in dLN of WT mice treated with local radiotherapy and antiCTLA-4 mAb [25], we measured tumor antigen-specific production of IFN $\gamma$ by dLN cells stimulated with a CD8 $\mathrm{T}$ cell epitope derived from the tumor antigen gp70 [31]. 


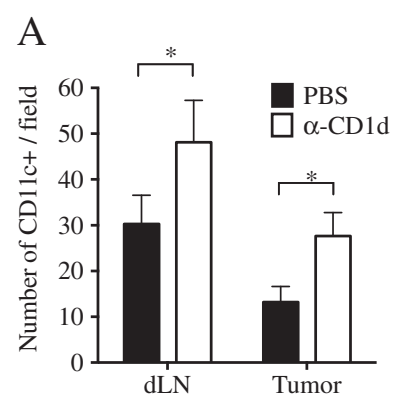

$\mathrm{D}$

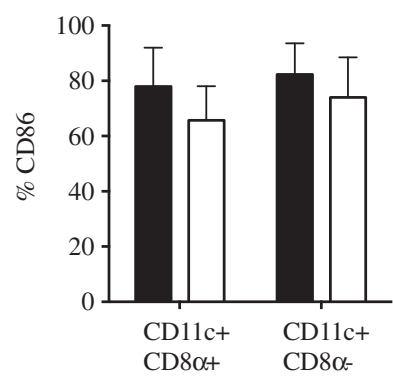

B

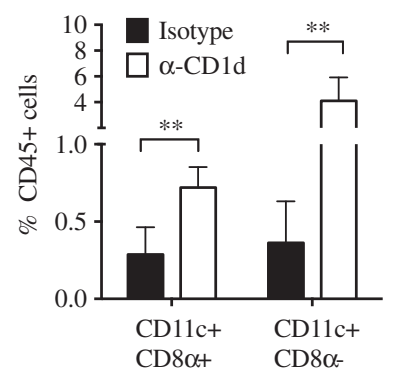

E

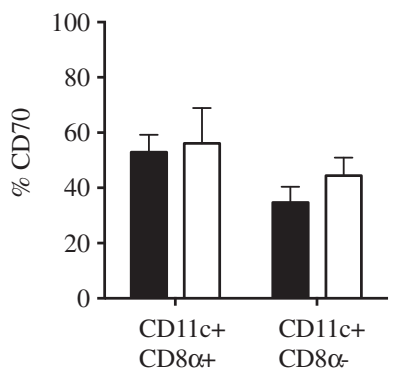

C

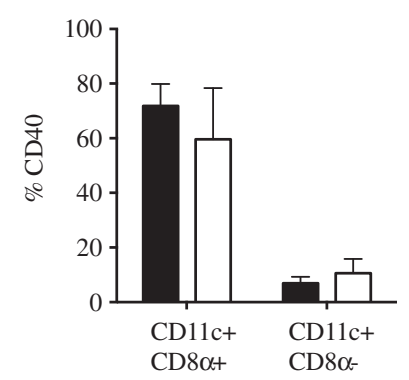

F

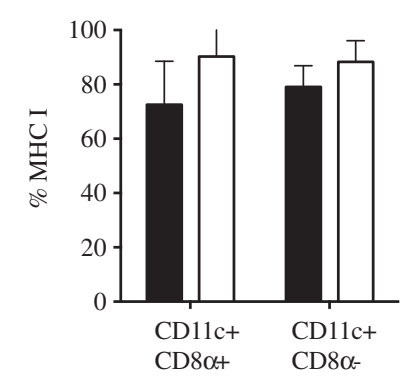

Figure 2 Blocking CD1d enhances DC numbers in 4T1 tumor-bearing WT mice. WT mice were inoculated with 4T1 cells on day 0 . On days 3, 7 and 11 mice were given either PBS (A) or Isotype mAb (B-F) (black bars) or anti-CD1d mAb (A-F) (white bars) i.p. (A) Tumors and dLN were excised on day 13, and tissue sections stained with anti-CD11 c mAb. Numbers are the mean \pm SD of 3 mice/group. Results are representative of two experiments. (B-F) In a separate experiment using the same blocking regimen, tumors were digested for flow cytometry analysis of dissociated cells ( $N=9 /$ group). To obtain sufficient material, each sample was prepared by pooling tumors from 3 mice, and 3 independent samples/group analyzed. (B) Samples were gated on CD45 + CD11C + cells, and analyzed for expression of (B) CD8a, and (C) CD40, (D) CD86, (E) CD70 and (F) MHC Class I molecules. ${ }^{*} p<0.05,{ }^{* *} p<0.005$.

No IFNy production was detected in dLNs from WT mice that were untreated or treated with RT or antiCTLA-4 alone (Figure 3). However, the combination of RT and anti-CTLA-4 induced significant tumor-specific IFN $\gamma$ production ( $\mathrm{p}<0.005$ versus all other groups), as expected given the therapeutic synergy we have previously shown with this combination [25,29,32]. Importantly, the response was significantly enhanced by blockade of CD1d (mean IFN- $\gamma 248.50 \pm 67.41 \mathrm{pg} / \mathrm{mL}$ in $\mathrm{RT}+$ anti-CTLA- 4 + anti-CD1d versus $88.62 \pm 19.80 \mathrm{pg} /$ $\mathrm{mL}$ in $\mathrm{RT}+$ anti-CTLA-4, $\mathrm{p}<0.005)$. Interestingly, tumor antigen-specific IFN- $\gamma$ production was detected in dLNs from untreated $\mathrm{iNKT}^{-/-}$mice $(33.08 \pm 10.04 \mathrm{pg} / \mathrm{mL}$ for AH1-A5 versus $9.65 \pm 10.86 \mathrm{pg} / \mathrm{mL}$ for $\mathrm{pMCMV}, \mathrm{p}=0.05$ ) (Figure 3), a finding consistent with the ability of these mice to inhibit lung metastases in a CD8-dependent manner [25]. This response was not affected by radiotherapy or anti-CTLA-4 as single treatment, but was dramatically increased by their combination $(696.12 \pm 109.22 \mathrm{pg} / \mathrm{mL}$, $\mathrm{p}<0.001$ versus control). Remarkably, IFN $\gamma$ response of dLN cells from mice treated with radiotherapy+ anti-CTLA-4 was seven fold higher in $\mathrm{iNKT}^{-/-}$compared to WT mice.
Overall, data strongly support the conclusion that iNKT cells perform a regulatory function and hinder the development of anti-tumor T cells in 4T1 tumor-bearing mice by controlling DC population that cross-present tumor-derived antigens in dLNs.

\section{CD1d blockade improves response to treatment with radiotherapy and anti-CTLA-4 in WT mice}

Next, we investigated whether the improved anti-tumor $\mathrm{T}$ cell response seen in the presence of CD1d blocking $\mathrm{mAb}$ results in improved tumor response to treatment. To this end, WT 4T1 tumor-bearing mice were treated with RT + anti-CTLA-4 in the presence or absence of CD1d blockade (Figure 4A). Treatment with RT and antiCTLA-4 was effective at controlling the primary irradiated tumor and extending significantly mice survival compared to control (median survival 41 versus 32.5 days, $\mathrm{p}<0.05$ ) (Figure 4B and C), as previously shown [29]. However, no complete tumor regression was achieved and all mice eventually succumbed to metastases. CD1d blockade did not have any effect by itself on tumor growth or survival, but it improved control of the irradiated tumor $(\mathrm{p}<0.05)$ and survival $(\mathrm{p}<0.05)$ of mice treated with RT and anti- 


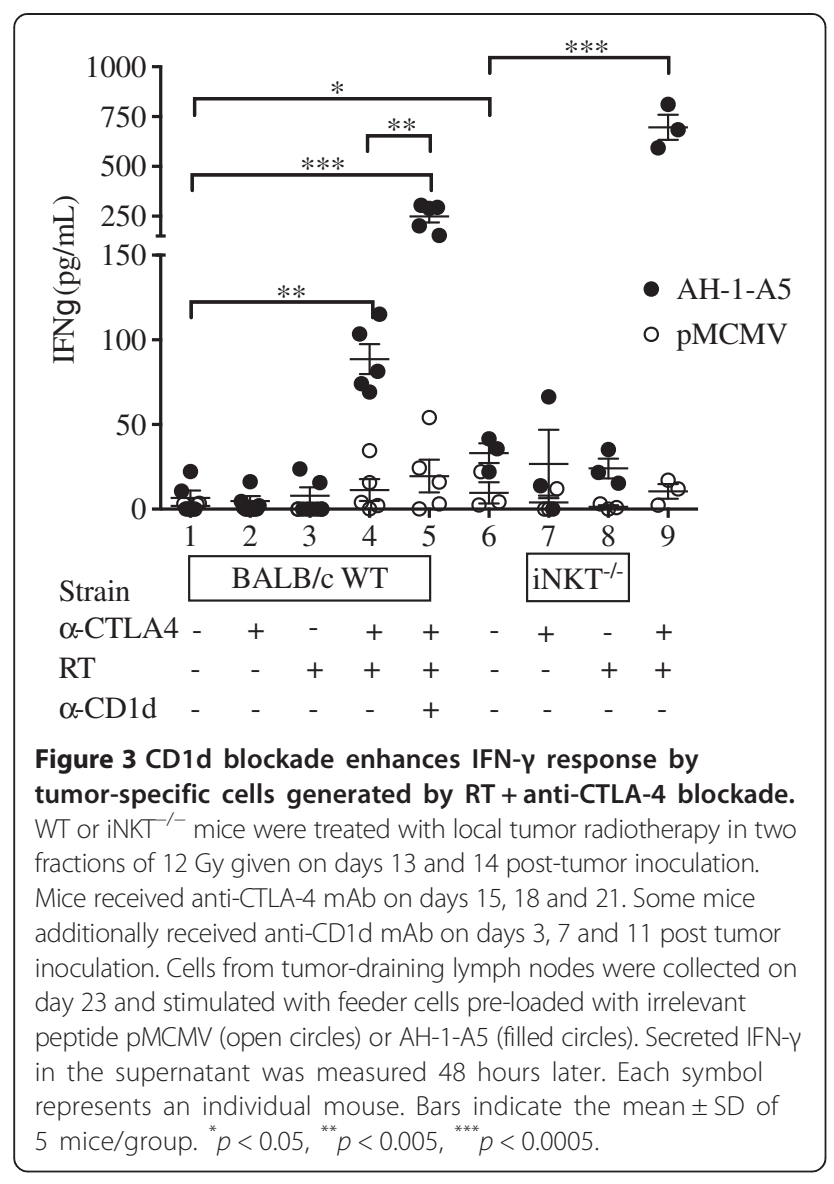

CTLA-4 (Figure 4B and C). Complete tumor regression was seen in $25 \%$ of the mice and these mice survived long-term and rejected a challenge of 4T1 cells 150 days after the initial inoculum (data not shown). Interestingly, CD1d blockade did not change significantly intra-tumoral levels of TNF- $\alpha$, IL-10, and IL- 4 in mice treated with radiation and anti-CTLA-4 (Figure 5B-D). IL-17 was undetectable in all conditions (data not shown). However, CD1d blockade enhanced significantly the levels of IFN $\gamma$ induced in tumors by treatment with radiation and antiCTLA-4 (Figure 5A), suggesting that iNKT cells hinder therapeutically effective Th1 responses in WT mice. Consistently, intra-tumoral levels of IFNY were high in iNKT ${ }^{-/-}$ mice treated with radiation and anti-CTLA- 4 and were not further increased by CD1d blockade. Similarly, IFN $\gamma$ was produced at significantly higher levels by spleen cells from mice treated with radiation and anti-CTLA-4 upon ex vivo activation in both $\mathrm{WT}$ and $\mathrm{iNKT}^{-/-}$mice, and it was further increased by CD1d blockade in WT but not $\mathrm{iNKT}^{-/-}$mice (Figure 6A). Interestingly, while IL-10 levels were low and were not affected by any of the treatments, IL-4 was produced at significantly higher levels by spleen cells of mice treated with RT + anti-CTLA-4 compared to control (Figure 6B and C). However, this effect was independent from iNKT cells since IL-4 levels were similar in
WT and iNKT ${ }^{-/-}$mice and were not enhanced by CD1d blockade in WT mice.

Taken together, these results indicate that iNKT cells can actively suppress the development and/or function of anti-tumor $\mathrm{T}$ cells and impair response to anti-CTLA-4 immunotherapy in $4 \mathrm{~T} 1$ tumor-bearing mice.

\section{iNKT cells regulate the response of 4T1 tumor-bearing mice to the combination of local radiotherapy and CD137 costimulation}

To determine whether negative regulation by iNKT cells could influence the response to a different immunotherapy, we tested treatment with local radiotherapy in combination with an agonistic anti-CD137 (4-1BB) mAb (Figure 7A). CD137 is a member of the tumor necrosis receptor superfamily that is upregulated shortly after T-cell activation [33]. CD137 ligation delivers a strong survival signal to T-cells, stimulates their effector function and promotes their differentiation into memory cells [34-37]. Importantly, we previously demonstrated that the combination of radiotherapy and CD137 costimulation was significantly more effective than each treatment alone in improving survival of mice with the intracranial GL261 glioma achieving tumor eradication in the majority of mice [38].

In both WT and $\mathrm{iNKT}^{-/-}$mice anti-CD137 mAb given as a single agent did not enhance survival compared to control untreated mice (median survival in WT mice: 39 days in control vs 40 days in anti-CD137 group, $\mathrm{p}=$ 0.36 iNKT $^{-/-}$mice: 42 days in control vs 46 days in anti-CD137 group, $\mathrm{p}=0.33$, Additional file 4: Figure S4). Consistent with previous observations that radiotherapy alone does not inhibit 4T1 lung metastases [29], median survival in WT or $\mathrm{iNKT}^{-/-}$mice given radiotherapy was not enhanced significantly (WT mice: 42 days, $\mathrm{p}=0.75$ compared to control; iNKT ${ }^{-1-}$ mice: 40 days, $\mathrm{p}=0.98$ compared to control). In contrast, radiotherapy and antiCD137 in combination significantly prolonged survival in WT (median survival 56 days, $\mathrm{p}<0.05$ compared to control) and $\mathrm{iNKT}^{-/-}$(median survival 60 days, $\mathrm{p}<0.005$ compared to control) mice (Figure 7C). Importantly, no complete tumor regression was achieved in WT mice treated with this combination and all mice eventually succumbed to metastases. In contrast, complete tumor regression and long-term survival was achieved in $50 \%$ of $\mathrm{iNKT}^{-/-}$mice treated with radiotherapy + anti-CD137 (Figure 7C). Furthermore, all of the long-term regressors were able to reject a tumorigenic challenge of viable 4T1 cells 120 days after the initial tumor implantation, indicating that they had developed a long-lasting protective immunological memory to the tumor (Figure 7D). To determine if blockade of CD1d in the context of radiotherapy and CD137 costimulation resulted in improved priming of anti-tumor $\mathrm{CD}^{+} \mathrm{T}$ cells in $\mathrm{dLN}$ of WT mice 


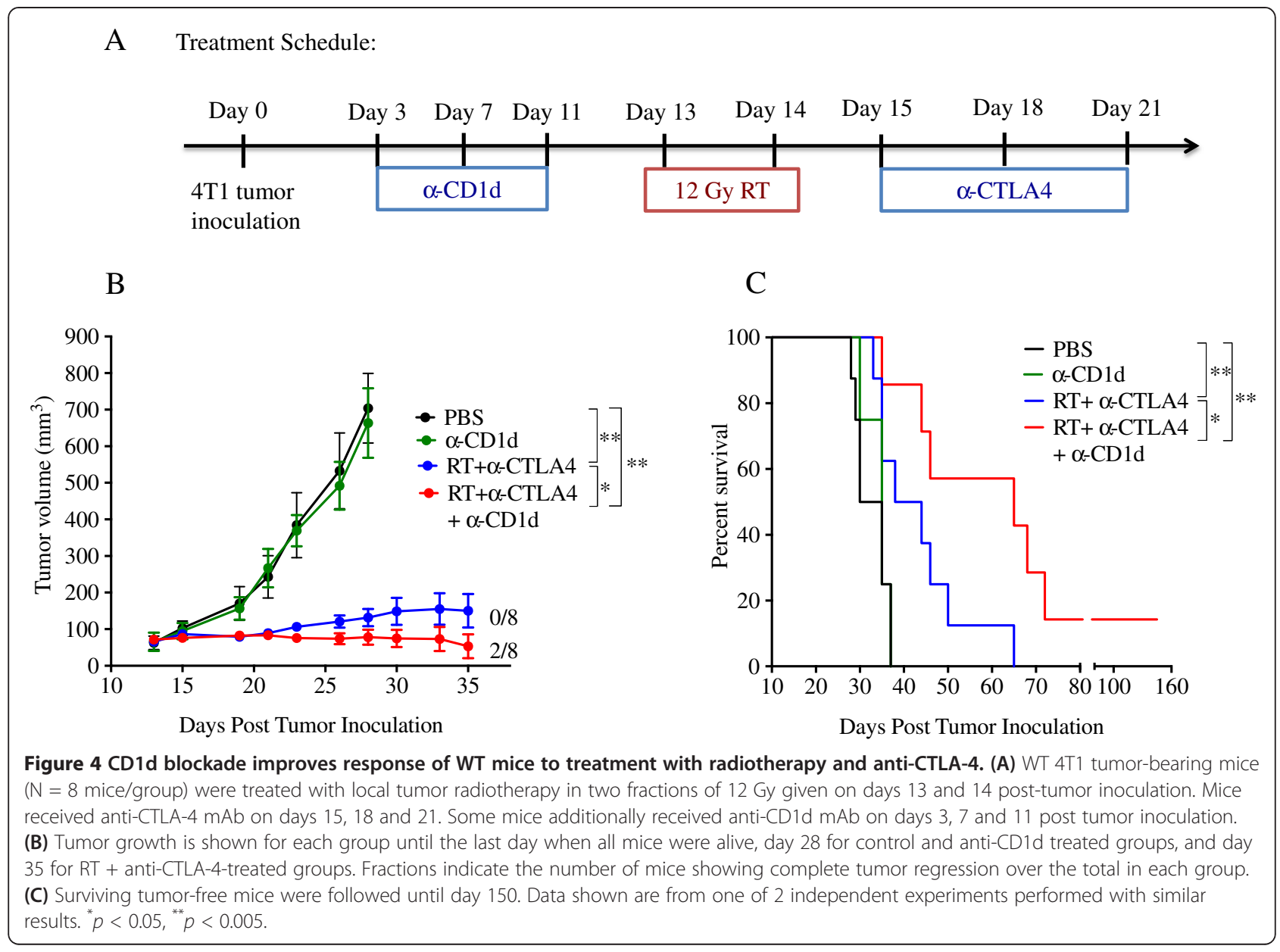

similar to that observed during anti-CTLA-4 blockade (Figure 3), we measured tumor antigen-specific production of IFNY by dLN cells. While mice treated with antiCD137 monotherapy did not show any peptide-specific IFNY production, treatment with the combination of RT and anti-CD137 induced significant tumor-specific IFNY production in both WT and iNKT ${ }^{-/-}$mice (Figure 8 ). Importantly, the response was markedly higher in iNKT ${ }^{-/-}$ mice and was significantly enhanced by in vivo blockade of CD1d in WT (mean IFN- $\gamma 109.03 \pm 13.85 \mathrm{pg} / \mathrm{mL}$ in $\mathrm{RT}+$ anti-CD137 + anti-CD1d versus $71.58 \pm 17.06 \mathrm{pg} / \mathrm{mL}$ in RT + anti-CD137, p < 0.05) but not iNKT-/- mice.

Overall, these results indicate that iNKT cells hinder priming of tumor-specific $\mathrm{CD}^{+} \mathrm{T}$ cells independent of the immune response modifier used in combination with radiotherapy to treat $4 \mathrm{~T} 1$ tumor-bearing mice.

\section{Discussion}

The 4T1 mouse mammary carcinoma is considered a model for the aggressive triple negative subtype of human breast cancer [39]. 4T1 cells are highly metastatic and relatively resistant to many immunotherapies once established, including anti-CTLA-4 treatment [29]. We have previously shown that the combination of local radiotherapy with anti-CTLA- 4 induces a $\mathrm{CD} 8^{+} \mathrm{T}$ cellmediated anti-tumor response effective at controlling the irradiated tumor as well as systemic metastases leading to increased survival of 4T1 tumor-bearing mice $[29,32,40]$. However, cures were rarely seen and most mice eventually succumbed to the tumor. Intriguingly, response to radiotherapy and anti-CTLA- 4 was markedly improved in mice lacking iNKT cells, achieving cures in $50 \%$ of the mice [25]. The improved response could not be attributed to altered immunogenicity of $4 \mathrm{~T} 1$ cells in $\mathrm{iNKT}^{-/-}$mice and could not be recapitu-

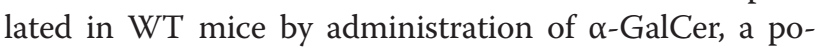
tent activator of iNKT cells anti-tumor activity in many tumor models $[12,13,41-44]$. Here we show that the improved response of $4 \mathrm{~T} 1$ tumor-bearing mice seen in the absence of iNKT cells is not unique to anti-CTLA-4based immunotherapy. Co-stimulation of $\mathrm{T}$ cells by antiCD137 in combination with radiotherapy was similarly more effective in iNKT ${ }^{-/-}$than WT mice and resulted in protective anti-tumor recall responses. These data further establish a negative regulatory role of iNKT cells in the 4T1 tumor model. 


\section{A}

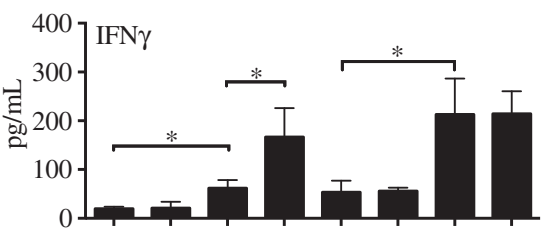

$\mathrm{C}$

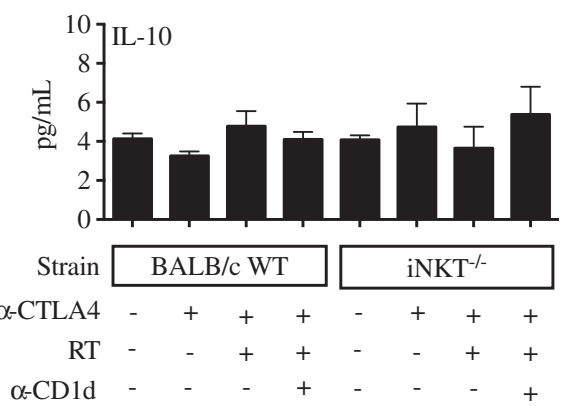

B

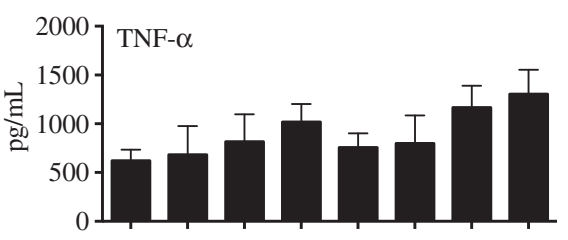

D

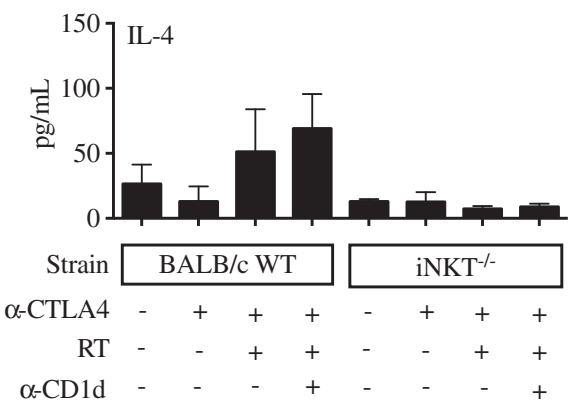

Figure $\mathbf{5}$ CD1d blockade enhances intratumoral IFN- $\gamma$ response induced by RT + anti-CTLA-4 blockade. WT and iNKT ${ }^{-1-}$ mice were treated with local tumor radiotherapy in two fractions of 12 Gy given on days 13 and 14 post-tumor inoculation. Mice received anti-CTLA-4 mAb on days 15, 18 and 21. Some mice additionally received anti-CD1d mAb or isotype mAb on days 3, 7 and 11 post tumor inoculation. Tumors were harvested at day 22 and concentration of (A) IFN- $\gamma$, (B) TNF-a, (C) IL-10 and (D) IL-4 were determined. Bars indicate the mean \pm SD of 4 mice/group. ${ }^{*} p<0.05$.

To understand the mechanisms of immune regulation by iNKT cells we examined DC, which are largely CD1d ${ }^{+}$, and are the APCs required for cross-presentation of tumor antigens to T cells $[45,46]$. Surprisingly, there was a reduction in the number of DCs present in the tumor and $\mathrm{dLN}$ of WT mice compared to $\mathrm{iNKT}^{-/-}$mice (Figure 1 ). Downregulation of surface CD11c molecules has been reported in TLR-activated mouse DCs [47]. We did not see any difference by flow cytometry in the levels of CD11c in DCs isolated from non-draining $\mathrm{LN}, \mathrm{dLN}$ and tumors (not shown), suggesting that CD11c downregulation induced by activation of DCs in the tumor of WT mice is not likely to account for locoregional reduction of DCs. Moreover, blocking the interaction of iNKT cells with DCs with anti-CD1d mAb led to an increase in both CD8 $\alpha+$ (immunostimulatory) and CD8 $\alpha$ - DCs in WT mice without affecting their activation state as measured by expression of costimulatory molecules (Figure 2). Overall, data indicate that iNKT cells regulate DCs numbers in the tumor and dLN.

Clearance of APC has been proposed as a mechanism to prevent unrestrained T-cell activation and proliferation, which is beneficial in preventing systemic autoimmunity [48] but detrimental for anti-tumor responses [49]. Several immune cells, including Tregs [26], NK cells [50] and CD8 ${ }^{+}$CTLs [49,51], have been implicated in direct elimination of DCs. We were unable to isolate tumor-infiltrating iNKT in sufficient quantities to test their ability to kill DCs ex vivo, but human iNKT cells have been shown to kill DCs in vitro [52], and it is possible that a similar mechanism is responsible for DC reduction in 4T1 tumor-bearing mice.

Blockade of CD1d in WT mice increased not only locoregional DC numbers, but also the priming of tumorspecific CD8 $\mathrm{T}$ cells in $\mathrm{dLN}$ and the overall tumor response to treatment with radiotherapy and antiCTLA-4 mAb, suggesting that temporarily "disabling" iNKT cells was sufficient to enhance Th1 type antitumor immunity. The increased production of IFN $\gamma$ in the tumor and spleen of WT mice treated with $\mathrm{RT}+$ anti-CTLA-4 in the presence of CD1d blockade supports this interpretation.

The overall better anti-tumor immunity and the high levels of IFNy seen in treated $\mathrm{iNKT}^{-1-}$ mice could be due to a larger population of immunostimulatory DC presenting tumor-derived antigens, but may also reflect skewing of the immune system that develops in BALB/c mice in the absence of iNKT cells towards Th1 rather than Th2 immunity [53]. IL-4 producing iNKT cells (NKT2) were recently described and shown to be the dominant iNKT subset in the thymus of BALB/c mice, and were implicated in determining the Th2 dominance of this mouse strain [53]. Among tumor-infiltrating iNKT cells, we found a larger percentage (6\%) that expressed markers (CD27 + CD122-) shown to define iNKT2 subset, while only $0.1 \%$ had markers of iNKT1 (CD27 + CD122+) 


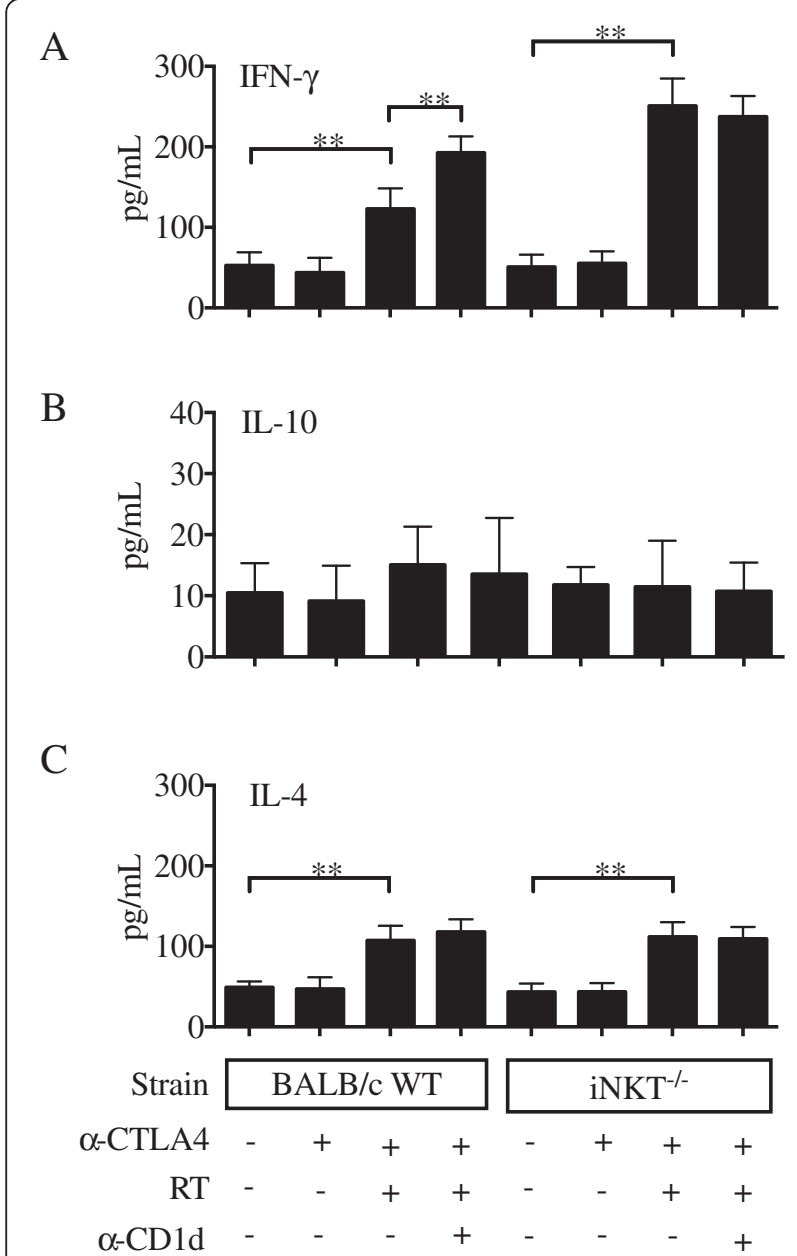

Figure $6 \mathrm{CD} 1 \mathrm{~d}$ blockade enhances systemic IFN- $\gamma$ response induced by RT + anti-CTLA-4 blockade. WT or iNKT ${ }^{-1}$ mice were treated with local tumor radiotherapy in two fractions of $12 \mathrm{~Gy}$ given on days 13 and 14 post-tumor inoculation. Mice received anti-CTLA-4 mAb on days 15, 18 and 21. Some mice additionally received anti-CD1d mAb or isotype mAb i.p. on days 3, 7 and 11 post tumor inoculation. Spleen were harvested at day 22 and concentration of (A) IFN- $\gamma$, (B) IL-10 and (C) IL-4 were measured in supernatants of PMA + ionomycin stimulated cells. Bars indicate the mean \pm SD of 4 mice/group. ${ }^{* *} p<0.005$.

cells (Additional file 5: Figure S5). However, the majority was CD27-CD122-, a phenotype associated with IL-17 production in the thymus [53]. Since IL-17 was undetectable in 4T1 tumors, defining the functional differentiation of iNKT cells in the tumor microenvironment may require different markers than in the thymus. Importantly, comparison between IL-4 levels produced in the tumor and spleen of tumor-bearing WT and $\mathrm{iNKT}^{-/-}$mice did not reveal significant differences consistent with differential Th2 polarization. Intratumoral IL-4 levels were higher in treated WT than $\mathrm{iNKT}^{-/-}$mice, but unlike IFN $\gamma$, IL-4 levels were not modulated by CD1d blockade (Figure 5D).
In the spleen IL- 4 was increased similarly in treated WT and $\mathrm{iNKT}^{-/-}$mice (Figure 6C).

iNKT cell role in promoting immune tolerance has been established in several experimental conditions, including autoimmune disease models, organ transplant and tolerance to oral antigens [23]. While multiple mechanisms have been suggested to play a role, to our knowledge control of DCs numbers by iNKT cells has not been previously documented in immune tolerance models or in the setting of cancer $[23,24,54,55]$. However, evidence that human iNKT cells can kill DCs in vitro [52], suggests that such mechanism could contribute to immunosuppression in some tumors and be responsible, at least in part, for the lack of clinical activity of $\alpha$-GalCer in cancer patients $[56,57]$. Consistent with this hypothesis, administration of $\alpha$-GalCer to $4 \mathrm{~T} 1$ tumor-bearing mice at day 15 posttumor inoculation failed to show any effect by itself or in combination with immunotherapy [25]. By this time, DCs are low in tumors and dLN (Figure 1), and the remaining DCs may be insufficient to present $\alpha-$ GalCer and/or may have acquired a tolerogenic phenotype.

The identity of the CD1d ligand(s) presented by DCs to iNKT cells in $4 \mathrm{~T} 1$ tumors and dLN is unknown. The endogenous lipids presented by CD1d in steady state conditions are likely to be non-antigenic or elicit tolerance. However, metabolic changes in the tumor may lead to altered lipid biosynthesis and generation of qualitatively or quantitatively modified CD1d ligands capable of triggering a different functional response of iNKT cells, further modulated by the inflammatory environment [23]. Improved understanding of the relationship between lipid metabolism in cancer and immune regulation will pave the way to the design of more effective immunotherapies that can enlist the power of iNKT cells to elicit strong anti-tumor immunity [58].

\section{Conclusions}

In this study we show that local reduction of DCs mediated by iNKT cells regulates the response to immunotherapy in a mouse model of aggressive breast cancer. The elimination of APC that cross-present tumor-derived antigens in dLNs was shown previously to be one mechanism of immunosuppression mediated by Tregs [26]. However, iNKT cells were believed to consistently perform antitumor activities, while immunosuppressive functions were ascribed to the non-invariant subset of NKT cells [59]. Here we demonstrate for the first time a novel mechanism of immune escape mediated by iNKT cells.

These results have important implications for the design of immunotherapies targeting iNKT cells (reviewed in [58]). CD1d blockade, or the iNKT-depleting antibody NKTT120 recently developed for inflammatory diseases [60], could have a role in treatment of cancers in which iNKT acquire immunosuppressive functions. 


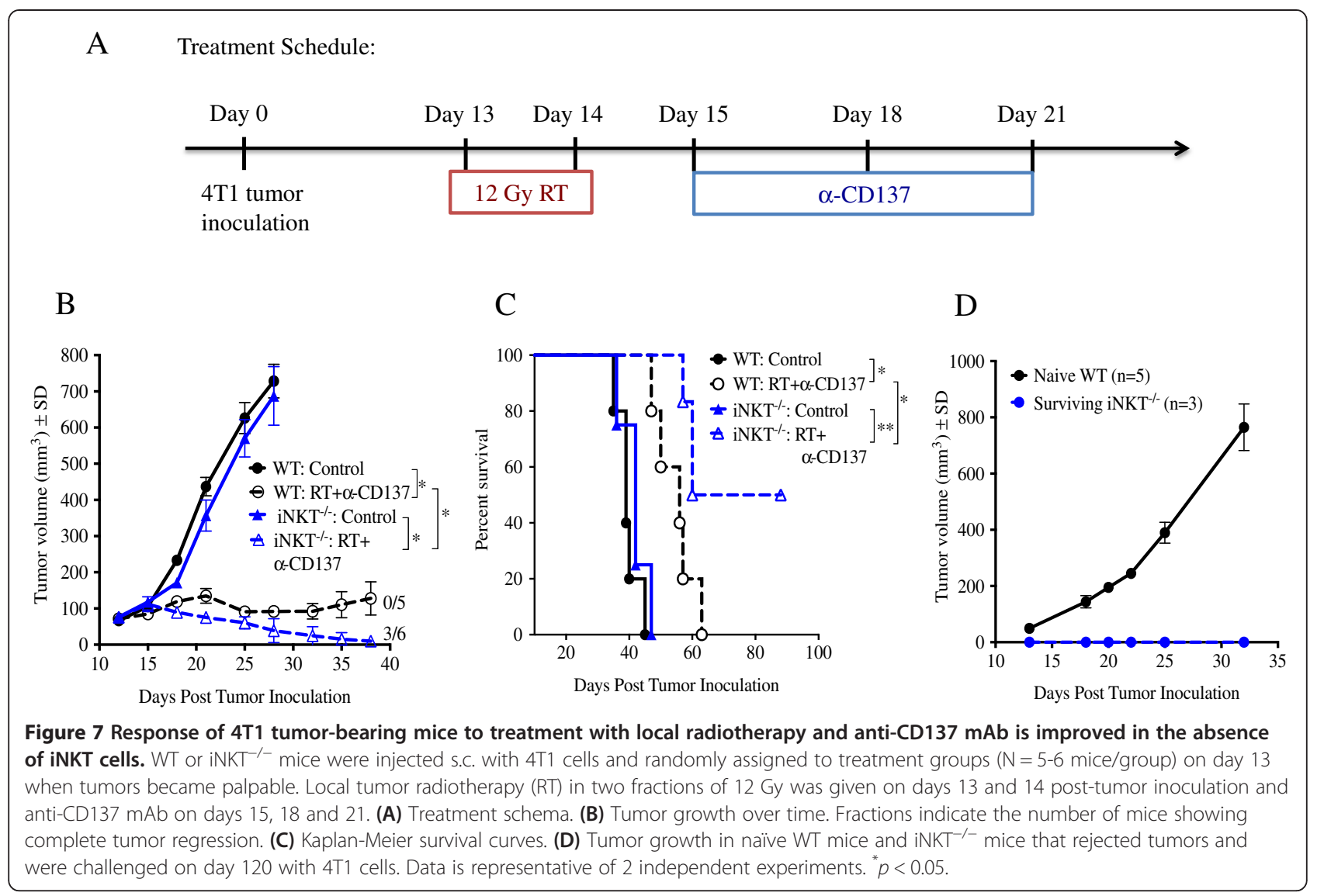

\section{Methods}

\section{Cells, antibodies and reagents}

4T1 is a BALB/c-derived mammary carcinoma that is highly metastatic and mimics the behavior of triple negative human breast cancer $[39,61]$. 4T1 cells were grown in complete medium consisting of DMEM (Invitrogen) supplemented with $2 \mathrm{~mol} / \mathrm{L}$ L-glutamine, $100 \mathrm{U} / \mathrm{mL}$ penicillin, $100 \mu \mathrm{g} / \mathrm{mL}$ streptomycin, $2.5 \times$ $10^{-5} \mathrm{~mol} / \mathrm{L} 2$-mercaptoethanol and $10 \%$ fetal bovine serum (BioWest). Cells were confirmed to be free of mycoplasma contamination using a mycoplasma detection kit (Sigma). DN32.D3 hybridoma cells, kindly provided by Masaki Terabe from the NCI Branch of the National Institutes of Health, were grown in supplemented RPMI (Invitrogen) [62]. Anti-CTLA-4 hamster monoclonal antibody (Clone 9H10) and anti-CD1d rat monoclonal antibody (Clone 20H2) were purchased from BioXCell (West Lebanon, NH). Control hamster IgG (isotype control for anti-CTLA-4) was purchased from Jackson Immunoresearch Laboratories. Control rat IgG1 (isotype control for anti-CD1d) was purchased from BioXCell. A rat IgG2a mAb against mouse CD137 (BMS469492, clone 1D8) was provided for these studies by Bristol-Myers Squibb (Princeton, NJ).

\section{Animals}

Six to eight-week old WT BALB/c mice were purchased from Taconic. iNKT ${ }^{-/-}$(Vo14J $\alpha 18$-deficient) mice [27] in the BALB/c background obtained from $M$. Taniguchi were bred at Berg Animal Facility at NYU School of Medicine and used between 6 to 8 weeks of age. All experiments were approved by the Institutional Animal Care and Use Committee of NYU Langone Medical Center.

\section{In vivo treatment}

Mice were inoculated subcutaneously (s.c.) with $5 \times 10^{4}$ 4T1 cells and randomly assigned to treatment groups 13 days later when tumors reached an average diameter of $5 \mathrm{~mm}$. Radiotherapy was given as previously described [25] with some modifications. Lightly anesthetized mice were positioned on a dedicated plexiglass tray with only the tumor area exposed to radiation while the rest of the body was protected by lead shielding. Radiotherapy was given using the Small Animal Radiation Research Platform (SARRP) (Gulmay Medical, Suwanee, GA) [63] in two doses of 12 Gy each on days 13 and 14 post tumor inoculation. Control hamster IgG and anti-CTLA-4 or anti-CD137/4-1BB mAbs were given at $200 \mu \mathrm{g}$ i.p. at 1, 4 and 7 days after completion of radiotherapy. To block 


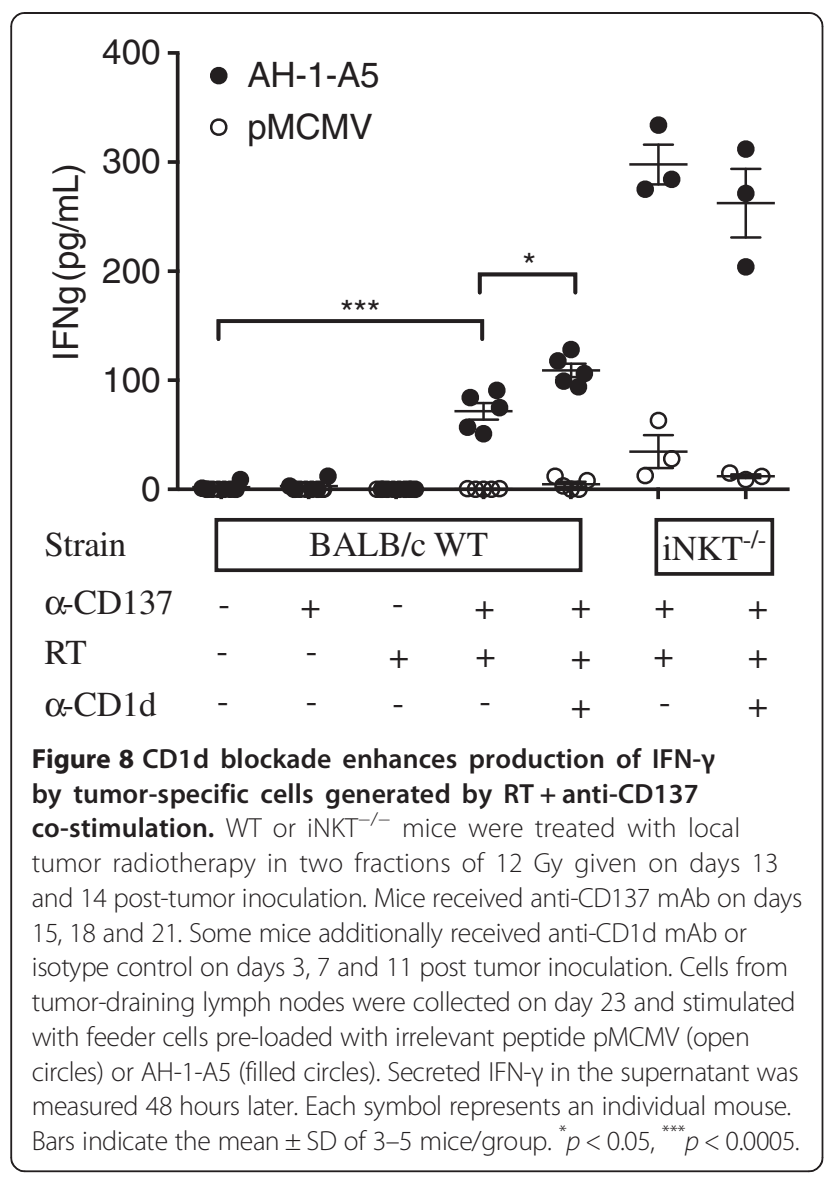

CD1d in vivo mice were given three doses of anti-CD1d mAb (Clone 20H2) at $100 \mu \mathrm{g}$ i.p. on days 3, 7 and 11 post tumor inoculation. Tumors were measured every 2-3 days until death or sacrifice when tumor dimensions exceeded $5 \%$ of body weight or if animals showed signs of significant pain or distress due to metastatic disease. In some experiments, mice that eradicated the tumor after treatment and remained tumor-free for at least 120 days were inoculated in the contralateral flank with 4T1 cells and tumor growth monitored. A group of naïve mice was similarly challenged with 4T1 cells as control.

\section{Immunohistochemistry}

4T1 tumors and dLNs were harvested on indicated days, fixed in freshly prepared $4 \%$ paraformaldehyde for $1 \mathrm{hr}$ at $4^{\circ} \mathrm{C}$ and incubated overnight in $30 \%$ sucrose. Tumors were then frozen in optimum cutting temperature (OCT) medium and stored at $-80^{\circ} \mathrm{C}$. Sections $(5 \mu \mathrm{m})$ were treated with $3 \% \mathrm{H}_{2} \mathrm{O}_{2}$ in PBS for 30 minutes in order to eliminate endogenous peroxide activity. After blocking in $4 \%$ hamster serum for an hour and three washes with PBS, antimouse CD11c eFluor 615 (eBioscience, San Diego, CA) was applied at a $1 / 100$ dilution in $1 \%$ BSA for 1 hour, followed by three washes and incubation in HRP- conjugated streptavidin (Jackson ImmunoResearch, West Grove, PA) at a 1/2,000 dilution in $1 \%$ BSA for 30 minutes. To amplify the signal, slides were subject to two rounds of biotin-tyramide amplification (PerkinElmer, Melville, NY) using manufacturer's suggested protocol. The slides were counterstained with DAPI, mounted with Vectashield and images obtained using a Nikon Eclipse 800 deconvolution microscope. Positive cells were counted from at least 3 randomly selected fields ( $20 \times$ magnification).

\section{Flow cytometry}

Lymph nodes and minced tumors were digested using a cocktail of 1.67 Wünsch U/mL Liberase TL (Roche) and $0.2 \mathrm{mg} / \mathrm{mL}$ DNAse (Roche) as previously described $[40,64]$. After lysis of red blood cells single cell suspensions were filtered through a $40-\mu \mathrm{m}$ nylon cell strainer. Live cells were distinguished using Fixable Viability Dye eFluor 660 (eBioscience) prior to flow staining. All samples were incubated with anti-mouse CD16/32 (Fc block) for 10 minutes followed by staining for various surface markers for 30 minutes at $4^{\circ} \mathrm{C}$. The following antibodies were used (all purchased from eBiosciences): PE-Cy7conjugated anti-mouse CD11c, Alexa Fluor 700-conjugated anti-mouse CD86, PE-conjugated anti-mouse CD80, PEconjugated anti-mouse CD1d, PE-conjugated anti-mouse CD70, FITC-conjugated anti-mouse CD40 and Alexa Fluor 700-conjugated anti-mouse MHC Class I $(\mathrm{H}-2 \mathrm{Kd}$ / Dd), FITC-conjugated anti-mouse CD27, PECy7-conjugated anti-mouse $\mathrm{CD} 3 \varepsilon$, APC-conjugated anti-mouse CD122, Alexa Fluor 700-conjugated anti-mouse CD4. iNKT cells were identified by staining with mouse CD1d/PBS-57 or CD1d/unloaded tetramers (NIH Tetramer Core Facility) for 30 minutes at room temperature [65]. All samples were analyzed using a BD LSR II flow cytometer and FlowJo version 8.7.5 (Tree Star).

\section{Ex vivo cytokine production}

Single cell suspensions $\left(3 \times 10^{5}\right.$ per well) from draining lymph nodes of $4 \mathrm{~T} 1$ tumor-bearing WT or iNKT ${ }^{-/-}$mice were cultured in complete T-cell medium in 48-well tissue culture plates with irradiated (12 Gy) feeder cells $\left(3 \times 10^{6}\right)$ prepared from the spleen of healthy $\mathrm{BALB} / \mathrm{c}$ mice pre-loaded with tumor-derived peptides (AH-1-A5) or an $\mathrm{H}-2 \mathrm{~L}^{\mathrm{d}}$-binding irrelevant peptide (pMCMV) used at a final concentration of $1 \mu \mathrm{g} / \mathrm{mL}$. Peptide sequences are SPSYAYHQF (AH-1-A5) [66], and YPHFMPTNL (pMCMV) [66]. After 48 hours, supernatants were collected and stored at $-80^{\circ} \mathrm{C}$. Secreted IFN- $\gamma$ was measured from duplicate wells using Flowcytomix kit (eBioscience, San Diego, CA). Background IFN- $\gamma$ production from supernatants of cells cultured in complete T-cell media alone was subtracted. Spleen cell suspensions $\left(10^{6}\right)$ from 4T1 tumor-bearing mice were cultured in a 24-well tissue 
culture plate and stimulated with PMA + ionomycin Cell Stimulation Cocktail Mix (eBioscience) for 48 hours.

\section{Intratumoral cytokines}

Freshly harvested tumors were immediately frozen in liquid nitrogen and stored at $-80^{\circ} \mathrm{C}$. To isolate total protein, tissues were thawed on ice, minced and homogenized in lysis buffer $(10 \mathrm{mM}$ Tris- $\mathrm{HCl}$ pH8.0, $150 \mathrm{mM} \mathrm{NaCl}, 1 \%$ NP-40, 10\% glycerol, $5 \mathrm{mM}$ EDTA) and protease inhibitor cocktail (Roche). Total volume $(\mu \mathrm{L})$ of lysis buffer used was equal to $5 \times$ weight of tumor tissue $(\mathrm{mg})$. Lysates were sonicated in $4^{\circ} \mathrm{C}$ using a 7 -minute regimen of 30s intermittent on and off. Samples were spun at 14,000 rpm for 15 minutes at $4^{\circ} \mathrm{C}$, supernatants collected and protein concentrations determined using Bradford assay. Samples were stored at $-80^{\circ} \mathrm{C}$. Cytokines were measured from duplicates wells using multi-analyte Flowcytomix kit.

\section{Statistical analysis}

Random coefficients regression (RCR) was used to assess the effect of treatment on tumor growth. The dependent variable was the natural log of tumor volume at all available times; log volumes were used since the change in log volume over the course of follow-up was well approximated as linear within each treatment arm. Log rank tests were used to compare treatment arms in terms of survival. The Kaplan-Meier method was used to estimate median survival times and the log cumulative hazard transformation was used to derive $95 \%$ confidence limits for median survival in each arm. All reported $\mathrm{p}$ values are twosided and statistical significance defined as $\mathrm{p}<0.05$. SAS 9.3 (SAS Institute, Cary, NC) was used for all computations.

\section{Additional files}

Additional file 1: Figure S1 Anti-CD1d mAb blocks cytokine production by DN32.D3 NKT-like hybridoma cells stimulated with a-GalCer-loaded DCs. CD11 $\mathrm{c}^{+}$bone-marrow derived dendritic cells (BMDC) from healthy BALB/c mice were plated in 24-well tissue culture plate $\left(2 \times 10^{4} /\right.$ well) and incubated with $100 \mathrm{ng} / \mathrm{mL}$ a-GalCer overnight, washed extensively and incubated overnight with fresh media containing anti-CD1d at indicated final concentrations. Cells were washed again before the addition of DN32.D3 hybridoma cells ( $10^{5} /$ well). Supernatants were collected three days later and cytokines measured.

\section{Additional file 2: Figure S2 Anti-CD1d mAb does not deplete} CD1d-expressing cells in vivo. Healthy WT mice ( $N=4$ /group) were given isotype or anti-CD1d mAb i.p. (200 $\mu \mathrm{g} /$ mouse) every 4 days for a total of 3 doses. Two days after the last dose, mice were euthanized and single cell suspensions from digested spleens collected for flow staining of (A) DC, (B) myeloid cells, (C) B-cells and (D) macrophage populations.

Additional file 3: Figure $S 3$ Anti-CD1d $m A b$ does not induce stimulation of CD1d-expressing APCs. Splenocytes from naïve WT or iNKT ${ }^{-1}$ mice $(n=4 /$ group) were stimulated in vitro with $10 \mathrm{\mu g} / \mathrm{mL}$ a-CD1d or isotype control mAbs for 48 hours. As a positive control, splenocytes were stimulated with LPS (1 $\mu \mathrm{g} / \mathrm{mL})$. Supernatants were collected and measured for secreted (A) IL-10, (B) IFN- $\gamma$, (C) IL-12p70 and (D) IL-4.
Additional file 4: Figure S4 Local tumor radiotherapy and CD137 co-stimulation used alone are ineffective in prolonging survival of 4T1 tumor-bearing mice. WT and iNKT ${ }^{-1-}$ mice were injected s.c. with $4 \mathrm{~T} 1$ cells and randomly assigned to treatment groups ( $n=5-6 /$ group) on day 13 when tumors became palpable. Local tumor radiotherapy (RT) was given in two fractions of 12 Gy on days 13 and 14 post-tumor inoculation. Mice received anti-CD137 mAb on days 15, 18 and 21. Kaplan-Meier curves were generated from survival data of each mouse calculated as time (days) from date of inoculation until death or euthanasia. Median survival (days) in each treatment group is indicated in parenthesis. Data is representative of 2 independent experiments.

Additional file 5: Figure S5 iNKT subset compartments in 4T1 tumors and tumor-draining lymph nodes. WT mice were injected s.c. with $4 \mathrm{~T} 1$ cells. On day 15 , tumor samples from three mice were pooled and digested to obtain single cell suspensions. (A) Intratumoral iNKT cells were identified using mouse CD1d/PBS-57 tetramers. Expression of surface CD122 and CD27 antigens were assessed on CD3+ CD1d/PBS-57 tetramer + populations to identify iNKT1 (CD27 + CD122+) and iNKT2 (CD27-CD122+) subsets. (B) The relative abundance of iNKT cells in the tumor and draining lymph nodes is shown as a percentage of total CD3 cells. (C) The relative abundance of iNKT1 (white bars) and INKT2 (black bars) subsets is shown as a percentage of total CD3+ CD1d/PBS-57 tetramer + cells. Bars indicate the mean \pm SD of three samples. ${ }^{* *} p<0.005$.

\section{Abbreviations}

a-GalCer: Alpha galactosylceramide; APC: Antigen presenting cells; BMDC: Bone marrow-derived dendritic cells; CD: Cluster of differentiation; CTL: Cytotoxic T lymphocytes; DCs: Dendritic cells; dLN: Draining lymph node; Gy: Gray; IFN- $\gamma$ : Interferon gamma; IHC: Immunohistochemistry; $\mathrm{NKT}^{-1-}$ : Invariant natural killer T cell-deficient; i.p.: Intraperitoneal; mAb: Monoclonal antibody; MHC: Major histocompatibility complex; ndLN: Non-draining lymph node; NK: Natural killer; PBS: Phosphate buffered saline; PMA: Phorbol 12-myristate 13-acetate; RT: Radiotherapy; s.c.: Subcutaneous; TAA: Tumor-associated antigens; Th1: T-helper type 1; Th2: T-helper type 2; Tregs: Regulatory T cells; WT: Wild type.

\section{Competing interests}

The authors declare that they have no competing interests.

\section{Authors' contributions}

KAP designed and performed all experiments and wrote the manuscript. JA carried out in vitro studies and immunostaining and contributed to writing the manuscript. SD conceived and designed the study with KAP and wrote the manuscript. JSB performed statistical analysis. All authors read and approved the final manuscript.

\section{Authors' information}

KAP started his postdoctoral fellowship at NYU School of Medicine and is currently an associate research scientist in the department of Pathology. JA is an undergraduate student at NYU College of Arts and Sciences. JSB has over 20 years experience as research biostatistician and is currently associate professor of Radiology at NYU School of Medicine. SD holds dual appointments as professor of Pathology and Radiation Oncology at NYU School of Medicine and is Co-leader of the Cancer Immunology program of the NYU Cancer Institute.

\section{Acknowledgments}

KAP was supported by a Postdoctoral Research Fellow Award (W81XWH-101-0007) from the US Department of Defense Breast Cancer Research Program. S. Demaria is supported by grants from the Chemotherapy Foundation, the US Department of Defense Breast Cancer Research Program (W81XWH-11-1-0532), and the Breast Cancer Alliance. The Histopathology and Flow Cytometry Core Facilities of the Laura and Isaac Perlmutter Cancer Center at the NYU Langone Medical Center are partially supported by NIH/NCI P30CA016087. The authors wish to thank Maria Jure-Kunkel (Bristol-Myers) for anti-CD137 mAb. We acknowledge the NIH Tetramer Core Facility (contract HHSN272201300006C) for provision of CD1d tetramers. 


\section{Author details}

'Department of Pathology, New York University School of Medicine, New York, NY 10016, USA. ²Department of Radiology, New York University School of Medicine, New York, NY 10016, USA. ${ }^{3}$ Department of Radiation Oncology, New York University School of Medicine, New York, NY 10016, USA. ${ }^{4} \mathrm{New}$ York University School of Medicine, Alexandria Center for Life Sciences, 450 East 29th St, Room 324B, New York, NY 10016, USA

Received: 3 March 2014 Accepted: 11 September 2014

Published online: 14 October 2014

\section{References}

1. Godfrey DI, Berzins SP: Control points in NKT-cell development. Nat Rev Immunol 2007, 7:505-518.

2. Taniguchi $M$, Seino $K$, Nakayama T: The NKT cell system: bridging innate and acquired immunity. Nat Immunol 2003, 4:1164-1165.

3. Juno JA, Keynan Y, Fowke KR: Invariant NKT cells: regulation and function during viral infection. PLOS Pathog 2012, 8:e1002838.

4. Bendelac $A: C D 1$ : presenting unusual antigens to unusual T lymphocytes. Science 1995, 269:185-186

5. Lantz $\mathrm{O}$, Bendelac $\mathrm{A}$ : An invariant $\mathrm{T}$ cell receptor alpha chain is used by a unique subset of major histocompatibility complex class I-specific CD4+ and CD4-8- T cells in mice and humans. J Exp Med 1994, 180:1097-1106.

6. Porcelli S, Yockey CE, Brenner MB, Balk SP: Analysis of T cell antigen receptor (TCR) expression by human peripheral blood CD4-8- alpha/beta $T$ cells demonstrates preferential use of several $\mathrm{V}$ beta genes and an invariant TCR alpha chain. J Exp Med 1993, 178:1-16.

7. Godfrey DI, MacDonald HR, Kronenberg M, Smyth MJ, Van Kaer L: NKT cells: what's in a name? Nat Rev Immunol 2004, 4:231-237.

8. Kawano T, Cui J, Koezuka Y, Toura I, Kaneko Y, Motoki K, Ueno H, Nakagawa R, Sato H, Kondo E, Koseki H, Taniguchi M: CD1d-restricted and TCR-mediated activation of valpha14 NKT cells by glycosylceramides. Science 1997, 278:1626-1629.

9. Matsuda JL, Naidenko OV, Gapin L, Nakayama T, Taniguchi M, Wang CR, Koezuka Y, Kronenberg M: Tracking the response of natural killer T cells to a glycolipid antigen using CD1d tetramers. J Exp Med 2000, 192:741-754.

10. Fujii S, Shimizu K, Smith C, Bonifaz L, Steinman RM: Activation of natural killer $T$ cells by alpha-galactosylceramide rapidly induces the full maturation of dendritic cells in vivo and thereby acts as an adjuvant for combined CD4 and CD8 T cell immunity to a coadministered protein. J Exp Med 2003, 198:267-279.

11. Nicol A, Nieda M, Koezuka Y, Porcelli S, Suzuki K, Tadokoro K, Durrant S, Juji T: Human invariant valpha24+ natural killer T cells activated by alpha-galactosylceramide (KRN7000) have cytotoxic anti-tumour activity through mechanisms distinct from T cells and natural killer cells. Immunology 2000, 99:229-234.

12. Kitamura H, Iwakabe $K$, Yahata T, Nishimura S, Ohta A, Ohmi Y, Sato M, Takeda K, Okumura K, Van Kaer L, Kawano T, Taniguchi M, Nishimura T: The natural killer T (NKT) cell ligand alpha-galactosylceramide demonstrates its immunopotentiating effect by inducing interleukin (IL)-12 production by dendritic cells and IL-12 receptor expression on NKT cells. J Exp Med 1999, 189:1121-1128.

13. Smyth MJ, Crowe NY, Pellicci DG, Kyparissoudis K, Kelly JM, Takeda K, Yagita $H$, Godfrey DI: Sequential production of interferon-gamma by NK1.1(+) $T$ cells and natural killer cells is essential for the antimetastatic effect of alpha-galactosylceramide. Blood 2002, 99:1259-1266.

14. Liu D, Song L, Brawley VS, Robison N, Wei J, Gao X, Tian G, Margol A Ahmed N, Asgharzadeh S, Metelitsa LS: Medulloblastoma expresses CD1d and can be targeted for immunotherapy with NKT cells. Clin Immunol 2013, 149:55-64.

15. Song L, Asgharzadeh S, Salo J, Engell K, Wu HW, Sposto R, Ara T, Silverman AM, DeClerck YA, Seeger RC, Metelitsa LS: Valpha24-invariant NKT cells mediate antitumor activity via killing of tumor-associated macrophages. J Clin Invest 2009, 119:1524-1536.

16. Uemura $Y$, Liu TY, Narita $Y$, Suzuki M, Nakatsuka R, Araki T, Matsumoto $M$, Iwai LK, Hirosawa N, Matsuoka Y, Murakami M, Kimura T, Hase M, Kohno H, Sasaki Y, Ichihara Y, Ishihara O, Kikuchi H, Sakamoto Y, Jiao SC, Senju S, Sonoda Y: Cytokine-dependent modification of IL-12p70 and IL-23 balance in dendritic cells by ligand activation of Valpha24 invariant NKT cells. J Immunol 2009, 183:201-208.
17. Yang YF, Tomura M, Ono S, Hamaoka T, Fujiwara H: Requirement for IFN-gamma in IL-12 production induced by collaboration between $v$ (alpha)14(+) NKT cells and antigen-presenting cells. Int Immunol 2000, 12:1669-1675

18. Crowe NY, Smyth MJ, Godfrey DI: A critical role for natural killer T cells in immunosurveillance of methylcholanthrene-induced sarcomas. J Exp Med 2002, 196:119-127.

19. Godfrey DI, Kronenberg M: Going both ways: immune regulation via CD1d-dependent NKT cells. J Clin Invest 2004, 114:1379-1388.

20. Kaieda S, Tomi C, Oki S, Yamamura T, Miyake S: Activation of invariant natural killer T cells by synthetic glycolipid ligands suppresses autoantibody-induced arthritis. Arthritis Rheum 2007, 56:1836-1845.

21. Miellot-Gafsou A, Biton J, Bourgeois E, Herbelin A, Boissier MC, Bessis N: Early activation of invariant natural killer T cells in a rheumatoid arthritis model and application to disease treatment. Immunology 2010, 130:296-306.

22. Miyamoto K, Miyake S, Yamamura T: A synthetic glycolipid prevents autoimmune encephalomyelitis by inducing $\mathrm{TH} 2$ bias of natural killer $\mathrm{T}$ cells. Nature 2001, 413:531-534.

23. Hegde S, Fox L, Wang X, Gumperz JE: Autoreactive natural killer T cells: promoting immune protection and immune tolerance through varied interactions with myeloid antigen-presenting cells. Immunology 2010, 130:471-483.

24. Hegde S, Lockridge JL, Becker YA, Ma S, Kenney SC, Gumperz JE: Human NKT cells direct the differentiation of myeloid APCs that regulate T cell responses via expression of programmed cell death ligands. J Autoimmun 2011, 37:28-38.

25. Pilones KA, Kawashima N, Yang AM, Babb JS, Formenti SC, Demaria S: Invariant natural killer T cells regulate breast cancer response to radiation and CTLA-4 blockade. Clin Cancer Res 2009, 15:597-606.

26. Boissonnas A, Scholer-Dahirel A, Simon-Blancal V, Pace L, Valet F, Kissenpfennig A, Sparwasser T, Malissen B, Fetler L, Amigorena S: Foxp3+ T cells induce perforin-dependent dendritic cell death in tumor-draining lymph nodes. Immunity 2010, 32:266-278.

27. Cui J, Shin T, Kawano T, Sato H, Kondo E, Toura I, Kaneko Y, Koseki H, Kanno M, Taniquchi M: Requirement for Valpha14 NKT cells in IL-12-mediated rejection of tumors. Science 1997, 278:1623-1626.

28. Roark JH, Park SH, Jayawardena J, Kavita U, Shannon M, Bendelac A: CD1.1 expression by mouse antigen-presenting cells and marginal zone B cells. $\mathrm{J}$ Immunol 1998, 160:3121-3127.

29. Demaria S, Kawashima N, Yang AM, Devitt ML, Babb JS, Allison JP, Formenti SC: Immune-mediated inhibition of metastases after treatment with local radiation and CTLA-4 blockade in a mouse model of breast cancer. Clin Cancer Res 2005, 11:728-734.

30. Demaria S, Ng B, Devitt ML, Babb JS, Kawashima N, Liebes L, Formenti SC: lonizing radiation inhibition of distant untreated tumors (abscopal effect) is immune mediated. Int J Radiat Oncol Biol Phys 2004, 58:862-870.

31. Yang D, Ud Din N, Browning DD, Abrams SI, Liu K: Targeting lymphotoxin beta receptor with tumor-specific T lymphocytes for tumor regression. Clin Cancer Res 2007, 13:5202-5210.

32. Ruocco MG, Pilones KA, Kawashima N, Cammer M, Huang J, Babb JS, Liu M, Formenti SC, Dustin ML, Demaria S: Suppressing T cell motility induced by anti-CTLA-4 monotherapy improves antitumor effects. J Clin Invest 2012, 122:3718-3730.

33. Hurtado JC, Kim SH, Pollok KE, Lee ZH, Kwon BS: Potential role of 4-1BB in T cell activation. Comparison with the costimulatory molecule CD28. J Immunol 1995, 155:3360-3367.

34. Shuford WW, Klussman K, Tritchler DD, Loo DT, Chalupny J, Siadak AW Brown TJ, Emswiler J, Raecho H, Larsen CP, Pearson TC, Ledbetter JA, Aruffo A, Mittler RS: 4-1BB costimulatory signals preferentially induce CD8+ T cell proliferation and lead to the amplification in vivo of cytotoxic $T$ cell responses. J Exp Med 1997, 186:47-55.

35. Chacon JA, Pilon-Thomas S, Sarnaik AA, Radvanyi LG: Continuous 4-1BB co-stimulatory signals for the optimal expansion of tumor-infiltrating lymphocytes for adoptive T-cell therapy. Oncoimmunology 2013, 2:e25581.

36. Chacon JA, Wu RC, Sukhumalchandra P, Molldrem JJ, Sarnaik A, Pilon-Thomas S, Weber J, Hwu P, Radvanyi L: Co-stimulation through 4-1BB/CD137 improves the expansion and function of CD8(+) melanoma tumor-infiltrating lymphocytes for adoptive T-cell therapy. PLOS ONE 2013, $8 \cdot e 60031$ 
37. Daniel-Meshulam I, Horovitz-Fried M, Cohen CJ: Enhanced antitumor activity mediated by human 4-1BB-engineered T cells. Int J Cancer 2013, 133:2903-2913.

38. Newcomb EW, Lukyanov Y, Kawashima N, Alonso-Basanta M, Wang SC, Liu M, Jure-Kunkel M, Zagzag D, Demaria S, Formenti SC: Radiotherapy enhances antitumor effect of anti-CD137 therapy in a mouse Glioma model. Radiat Res 2010, 173:426-432.

39. Kaur P, Nagaraja GM, Zheng H, Gizachew D, Galukande M, Krishnan S, Asea A: A mouse model for triple-negative breast cancer tumor-initiating cells (TNBC-TICS) exhibits similar aggressive phenotype to the human disease. BMC Cancer 2012, 12:120

40. Matsumura S, Wang B, Kawashima N, Braunstein S, Badura M, Cameron TO, Babb JS, Schneider RJ, Formenti SC, Dustin ML, Demaria S: Radiation-induced CXCL16 release by breast cancer cells attracts effector T cells. J Immunol 2008, 181:3099-3107.

41. Hayakawa Y, Rovero S, Forni G, Smyth MJ: Alpha-galactosylceramide (KRN7000) suppression of chemical- and oncogene-dependent carcinogenesis. Proc Natl Acad Sci U S A 2003, 100:9464-9469.

42. Kawano T, Cui J, Koezuka Y, Toura I, Kaneko Y, Sato H, Kondo E, Harada M, Koseki H, Nakayama T, Tanaka Y, Taniguchi M: Natural killer-like nonspecific tumor cell lysis mediated by specific ligand-activated Valpha14 NKT cells. Proc Natl Acad Sci U S A 1998, 95:5690-5693.

43. Metelitsa LS, Naidenko OV, Kant A, Wu HW, Loza MJ, Perussia B, Kronenberg M, Seeger RC: Human NKT cells mediate antitumor cytotoxicity directly by recognizing target cell CD1d with bound ligand or indirectly by producing IL-2 to activate NK cells. J Immunol 2001, 167:3114-3122.

44. Nakagawa R, Motoki K, Nakamura H, Ueno H, lijima R, Yamauchi A, Tsuyuki $\mathrm{S}$, Inamoto T, Koezuka Y: Antitumor activity of alpha-galactosylceramide, KRN7000, in mice with EL-4 hepatic metastasis and its cytokine production. Oncol Res 1998, 10:561-568.

45. Fujii S, Shimizu K, Hemmi H, Steinman RM: Innate Valpha14(+) natural killer T cells mature dendritic cells, leading to strong adaptive immunity. Immunol Rev 2007, 220:183-198.

46. Melief CJ: Mini-review: regulation of cytotoxic T lymphocyte responses by dendritic cells: peaceful coexistence of cross-priming and direct priming? Eur J Immunol 2003, 33:2645-2654.

47. Singh-Jasuja H, Thiolat A, Ribon M, Boissier MC, Bessis N, Rammensee HG, Decker P: The mouse dendritic cell marker CD11c is down-regulated upon cell activation through Toll-like receptor triggering. Immunobiology 2013, 218:28-39.

48. Stranges PB, Watson J, Cooper CJ, Choisy-Rossi CM, Stonebraker AC, Beighton RA, Hartig H, Sundberg JP, Servick S, Kaufmann G, Fink PJ, Chervonsky AV: Elimination of antigen-presenting cells and autoreactive T cells by Fas contributes to prevention of autoimmunity. Immunity 2007, 26:629-641.

49. Hermans IF, Ritchie DS, Yang J, Roberts JM, Ronchese F: CD8+ T cell-dependent elimination of dendritic cells in vivo limits the induction of antitumor immunity. J Immuno/ 2000, 164:3095-3101.

50. Castriconi R, Cantoni C, Della Chiesa M, Vitale M, Marcenaro E, Conte R, Biassoni R, Bottino C, Moretta L, Moretta A: Transforming growth factor beta 1 inhibits expression of NKp30 and NKG2D receptors: consequences for the NK-mediated killing of dendritic cells. Proc Natl Acad Sci U S A 2003, 100:4120-4125.

51. Yang J, Huck SP, McHugh RS, Hermans IF, Ronchese F: Perforin-dependent elimination of dendritic cells regulates the expansion of antigen-specific CD8+ T cells in vivo. Proc Natl Acad Sci U S A 2006, 103:147-152.

52. Nicol A, Nieda M, Koezuka Y, Porcelli S, Suzuki K, Tadokoro K, Durrant S, Juji T: Dendritic cells are targets for human invariant Valpha24+ natural killer T-cell cytotoxic activity: an important immune regulatory function. Exp Hematol 2000, 28:276-282.

53. Lee YJ, Holzapfel KL, Zhu J, Jameson SC, Hogquist KA: Steady-state production of IL-4 modulates immunity in mouse strains and is determined by lineage diversity of iNKT cells. Nat Immunol 2013, 14:1146-1154.

54. Hegde S, Chen X, Keaton JM, Reddington F, Besra GS, Gumperz JE: NKT cells direct monocytes into a DC differentiation pathway. J Leukoc Biol 2007, 81:1224-1235.

55. Hegde S, Jankowska-Gan E, Roenneburg DA, Torrealba J, Burlingham WJ, Gumperz JE: Human NKT cells promote monocyte differentiation into suppressive myeloid antigen-presenting cells. J Leukoc Biol 2009, 86:757-768.

56. Giaccone G, Punt CJ, Ando Y, Ruijter R, Nishi N, Peters M, von Blomberg BM, Scheper RJ, van der Vliet HJ, van den Eertwegh AJ, Roelvink M, Beijnen J,
Zwierzina H, Pinedo HM: A phase I study of the natural killer T-cell ligand alpha-galactosylceramide (KRN7000) in patients with solid tumors. Clin Cancer Res 2002, 8:3702-3709.

57. Imataki $O$, Heike $Y$, Makiyama $H$, lizuka A, Ikarashi $Y$, Ishida $T$, Wakasugi $H_{\text {, }}$ Takaue Y: Insufficient ex vivo expansion of Valpha24(+) natural killer T cells in malignant lymphoma patients related to the suppressed expression of CD1d molecules on CD14(+) cells. Cytotherapy 2008, 10:497-506

58. Pilones KA, Aryankalayil J, Demaria S: Invariant NKT cells as novel targets for immunotherapy in solid tumors. Clin Dev Immunol 2012, 2012:720803.

59. Terabe M, Swann J, Ambrosino E, Sinha P, Takaku S, Hayakawa $Y$, Godfrey DI, Ostrand-Rosenberg S, Smyth MJ, Berzofsky JA: A nonclassical non-Valpha14Jalpha18 CD1d-restricted (type II) NKT cell is sufficient for down-regulation of tumor immunosurveillance. J Exp Med 2005, 202:1627-1633.

60. Scheuplein F, Thariath A, Macdonald S, Truneh A, Mashal R, Schaub R: A humanized monoclonal antibody specific for invariant natural killer T (iNKT) cells for in vivo depletion. PLOS ONE 2013, 8:e76692.

61. Aslakson CJ, Miller FR: Selective events in the metastatic process defined by analysis of the sequential dissemination of subpopulations of a mouse mammary tumor. Cancer Res 1992, 52:1399-1405.

62. Bendelac A, Lantz O, Quimby ME, Yewdell JW, Bennink JR, Brutkiewicz RR: CD1 recognition by mouse NK1+ T lymphocytes. Science 1995, 268:863-865.

63. Wong J, Armour E, Kazanzides P, lordachita I, Tryggestad E, Deng H, Matinfar M, Kennedy C, Liu Z, Chan T, Gray O, Verhaegen F, McNutt T, Ford E, DeWeese TL: High-resolution, small animal radiation research platform with x-ray tomographic guidance capabilities. Int J Radiat Oncol Biol Phys 2008, 71:1591-1599.

64. Quezada SA, Peggs KS, Simpson TR, Shen Y, Littman DR, Allison JP: Limited tumor infiltration by activated $T$ effector cells restricts the therapeutic activity of regulatory $\mathrm{T}$ cell depletion against established melanoma. $J$ Exp Med 2008, 205:2125-2138.

65. Liu Y, Goff RD, Zhou D, Mattner J, Sullivan BA, Khurana A, Cantu C 3rd Ravkov EV, Ibegbu CC, Altman JD, Teyton L, Bendelac A, Savage PB: A modified alpha-galactosyl ceramide for staining and stimulating natural killer T cells. J Immunol Methods 2006, 312:34-39.

66. Slansky JE, Rattis FM, Boyd LF, Fahmy T, Jaffee EM, Schneck JP, Margulies DH, Pardoll DM: Enhanced antigen-specific antitumor immunity with altered peptide ligands that stabilize the MHC-peptide-TCR complex. Immunity 2000, 13:529-538.

doi:10.1186/s40425-014-0037-x

Cite this article as: Pilones et al:: Invariant natural killer T cells regulate anti-tumor immunity by controlling the population of dendritic cells in tumor and draining lymph nodes. Journal for ImmunoTherapy of Cancer 20142.37.

\section{Submit your next manuscript to BioMed Central and take full advantage of:}

- Convenient online submission

- Thorough peer review

- No space constraints or color figure charges

- Immediate publication on acceptance

- Inclusion in PubMed, CAS, Scopus and Google Scholar

- Research which is freely available for redistribution 